\title{
OCCURRENCE AND BREEDING OF THE EASTERN SCREECH-OWL NORTH OF THE RIDING MOUNTAINS, MANITOBA
}

\author{
WILLIAM J. WALLEY, 222 Bossons Avenue, Dauphin, MB. R7N OR2 and \\ CLAUDETTE F. CLYDE, Box 801, Dauphin, MB. R7N 3B3
}

The geographical range of the Eastern Screech-Owl in western Manitoba extends north to Riding Mountain National Park (RMNP). ${ }^{5}$ In a comprehensive study by Adam, the species was recorded much further north in Saskatchewan and Alberta than in Manitoba. ${ }^{1}$ On the basis of available data, Adam concluded that a Wasagaming record at the southern boundary of RMNP was probably the northernmost for Manitoba.

From 1971 to 1993 , Walley documented records of Eastern ScreechOwls north of the Riding Mountains, primarily in the Dauphin region. Inquiries made of long-time residents of the area indicated that the owl has occurred in the region north of RMNP for at least 45 years.

Early Records While many observers can identify our common birds, most do not recognize unusual or uncommon birds such as small owls. Could some of the owls reported as Eastern Screech-Owls or "tiny owls with tufts on the head" actual have been other species? Boreal Owls have been described by one writer as having tiny feather tufts which can be seen when viewed in certain postures. ${ }^{16}$ Of winter sightings (Table 1 ), over $85 \%$ of the 22 records were reported by observers familiar with the owl or by specimens (frozen birds) or photographs. Moreover, unless specifically sought, the miniscule feather tufts of the Boreal Owl would be easily overlooked. Standard field guides show no feather tufts for Boreal Owls. ${ }^{5,9,14}$ It is also unlikely that Northern Saw-whet Owls were mistaken for screechowls. This species has no feather tufts and is migratory from the region. ${ }^{5}$ In addition, over $80 \%$ of the spring owls (Table 1) were identified from their territorial calls by the senior author.

Among the early reporters of screech-owls in the region, two of four observers, Ed Siwicki and Charlie Bancarz, recognized the species amid other raptor mounts in the Biology room at the Dauphin Regional Comprehensive Secondary School. At Roblin near the Saskatchewan boundary $\left(51^{\circ} 28^{\prime} \mathrm{N} ; 101^{\circ} 10^{\prime} \mathrm{W}\right)$, in the late 1940s, tiny owls with feather tufts on the head were seen and eventually found frozen near the barn (E. Siwicki, pers. comm.). Bancarz (pers. comm.) saw "barn owls" with little tufts on the head that spent the winter catching sparrows in the barn on their farm $29 \mathrm{~km}$ north of Roblin in the early 1950s. In the winter of 1965 a small owl with feather tufts perched all day by the house at the Carmichael farm just north of RMNP (B. Carmichael, pers. comm.). Closer to the study area an injured small owl with "horns" was found at a farm north of Gilbert Plains in the winter of 1984 (E. Hnatiuk, pers. comm.). 


\begin{tabular}{|c|c|c|}
\hline \multicolumn{3}{|c|}{ 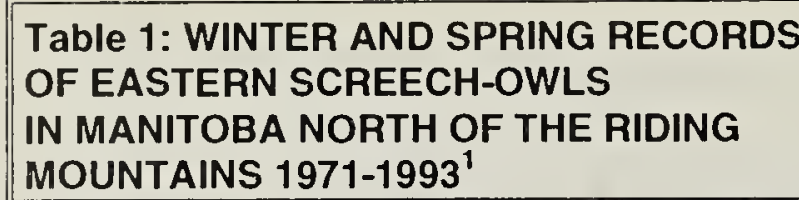 } \\
\hline Year & Winter $^{2}$ & Spring $^{3}$ \\
\hline 1971 & & 1 \\
\hline 1973 & & 2 \\
\hline 1974 & & 1 \\
\hline 1975 & & 1 \\
\hline 1976 & 1 & 2 \\
\hline 1977 & 2 & 1 \\
\hline 1978 & 2 & \\
\hline 1979 & $6-7$ & 2 \\
\hline 1980 & & 2 \\
\hline 1981 & 1 & 2 \\
\hline 1982 & & 1 \\
\hline 1983 & 1 & \\
\hline 1984 & & 2 \\
\hline 1985 & 2 & \\
\hline 1986 & 1 & 1 \\
\hline 1987 & 1 & 1 \\
\hline 1989 & 2 & \\
\hline 1991 & & 1 \\
\hline 1992 & 1 & \\
\hline 1993 & 2 & $2+^{4}$ \\
\hline Total & $22-23^{5}$ & $22^{6}$ \\
\hline \multicolumn{3}{|c|}{$\begin{array}{l}1 \text { within } 400 \mathrm{~km}^{2} \text { of Dauphin } \\
2 \text { most reported to the authors by others, } \\
\text { mainly farmers } \\
{ }^{3} \text { most located by Walley through call } \\
\text { recognition } \\
{ }^{4} \text { mated pair and } 5 \text { young } \\
5 \text { 11 locations in } 12 \text { different years } \\
69 \text { locations in } 15 \text { different years }\end{array}$} \\
\hline
\end{tabular}

Recent Records The occurrence of the Eastern Screech-Owl at barns where the principle prey apparently is sparrows, is well documented. ${ }^{2,3,13}$ In this study, $73 \%$ of the winter records (Table 1) were of owls at, or near, barns or granaries in farmyards. The late Hilton Kotyk watched an owl in his farmyard SW of Dauphin from 1-20 January 1985. The owl left when the House Sparrow population was depleted. At the Baker farm along the Valley River just west of Lake Dauphin, Eastern Screech-Owls usually arrived at the barn in January when large numbers of House Sparrows were present. Two owls were found frozen at this location in the winter of 1993 (A.
Baker, pers. comm.). Of course mice are also taken by the owls as observed at the Rampton barn just SW of Dauphin in February 1987 (K. Leonard, pers. comm.).

Eastern Screech-Owls also occurred in the town of Dauphin. On the evening of 2 March 1989 Walley was called to a residential area in the north end of town where a gray phase bird slept on a horizontal limb of a Green Ash (Fraxinus pennsylvanica var. subintegerima) in $-33^{\circ} \mathrm{C}$ temperatures. House Sparrows were abundant in the area. In the winter of 1978, four small owls were reported in Dauphin in late January and midFebruary. Given the rareness of Boreal Owls - we have one record of this species between 1971 and 1993 from the boreal forest of the Duck Mountains some $100 \mathrm{~km}$ NW of Dauphin - and the absence of the Northern Saw-whet Owls in winter, it is quite possible that these owls were also screech-owls. In the village of Sifton (Figure 1) during December of 1985 or 1986 a trap, placed on the cage of a pet ferret that was being harassed at night, caught a $20 \mathrm{~cm}$ long owl with feather tufts (S. Wellborn, pers. comm.).

The 44 records of owls in Table 1 certainly include only some of the actual occurrences of the species in the area. This was indicated in 1985 when a Parks Canada warden informed us that many farmers, unaware of the illegality of the practice, had told him they had owls to stuff the birds having died in barns where they kept the sparrows down.

The northernmost record of the Eastern Screech-Owl in Manitoba was a gray phase bird found frozen in the Kenville Pioneer elevator at $52^{\circ} 00^{\prime} \mathrm{N}$ latitude just south of Swan River in January 1993. The specimen was delivered to Hugh Hornbeck by Bud Shadholt. 


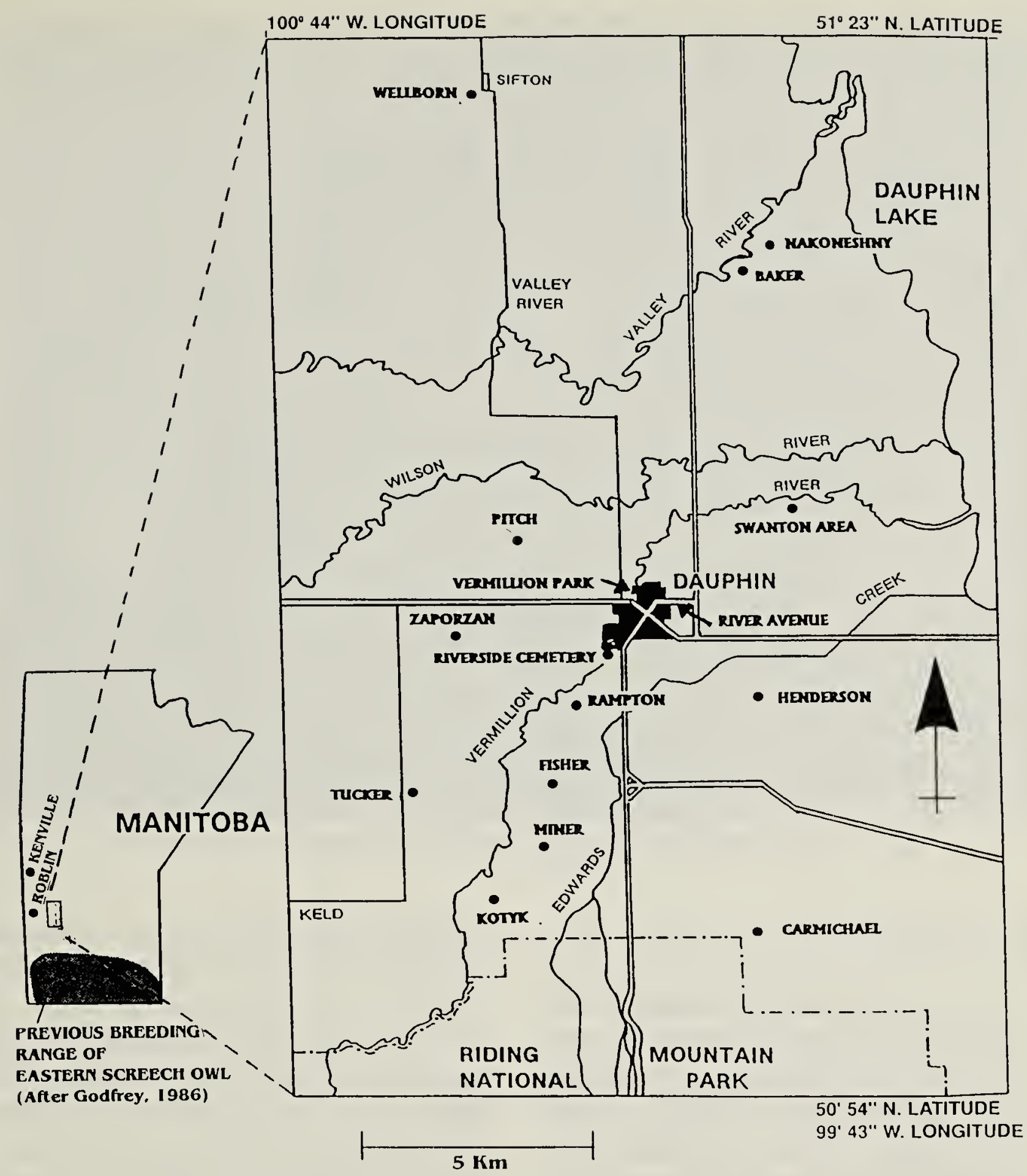

Figure 1. Locations of Eastern Screech-Ow/s near Dauphin, Manitoba, 1971-1973.

The seasonal pattern of distribution of the screech-owl appears to be farmyards in winter and dispersal into gallery forests along river courses in spring, presumably to establish territories and nest. In spring, the owls are the most vocal and have been identified by their calls, often in response to playback of recordings of their vocalizations. Riparian habitat includes mature stands of Manitoba Maple (Acer negundo), American Elm (Ulmus americana) and Green Ash, with some Trembling Aspen (Populus tremuloides), Paper Birch (Betula papyrifera) and
Balsam Poplar (Populus balsamifera). These tree species provide an abundance of nesting and roosting cavities. However, a nest box project initiated by us in the early 1990s along the Vermillion, Wilson and Valley rivers failed to attract nesting screech-owls, although we were unable to check some of the boxes some years due to high water levels. Most of the boxes were apparently taken over by Gray Squirrels that lined them with leaves. Only one spring record of the owl was found in non-riparian woods. This was in Trembling Aspen-Bur Oak (Quercus 


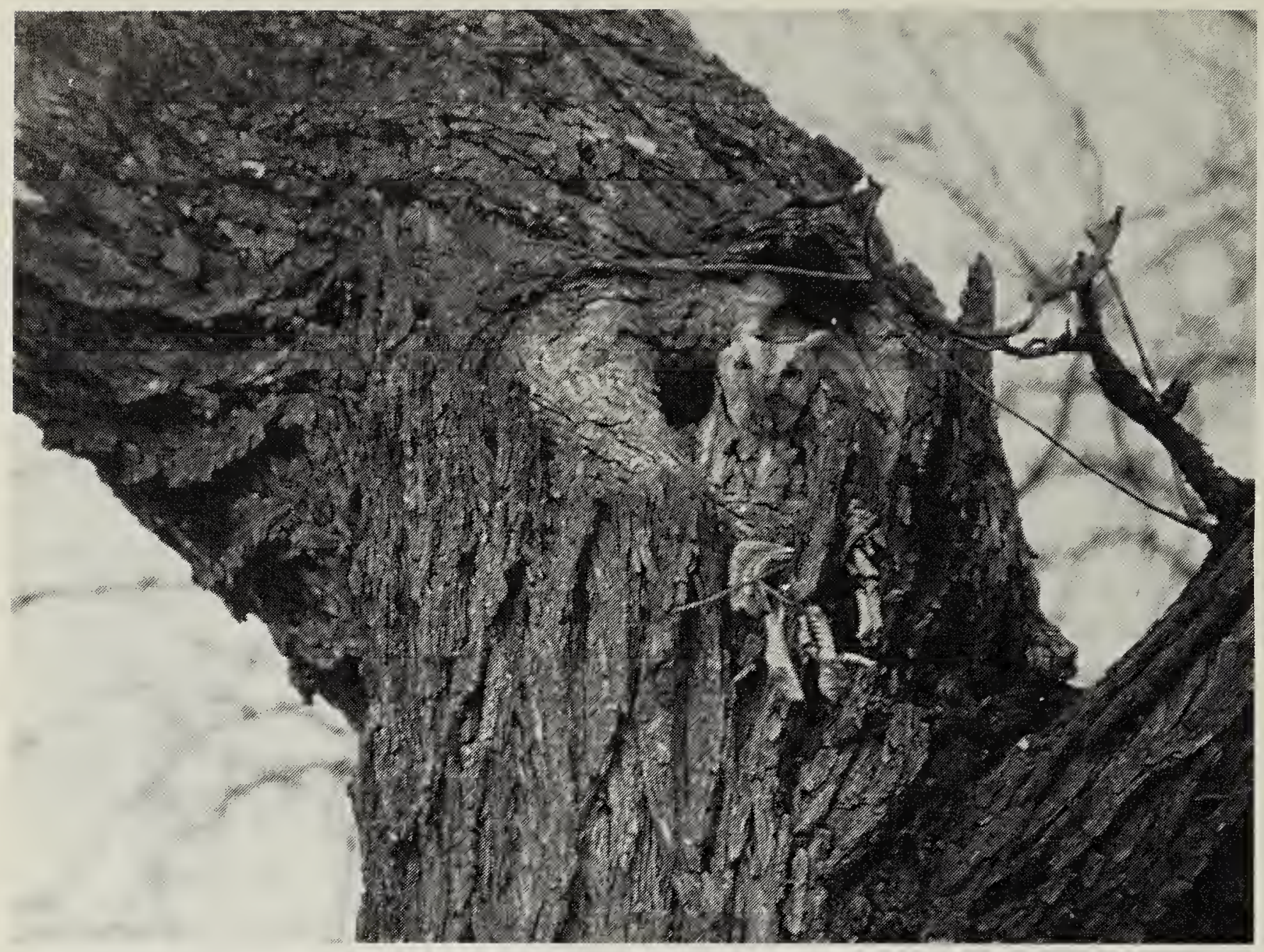

Figure 2. Male Eastern Screech-Owl (gray phase) at roost in elm.

macrocarpa) woods.

It is possible that the records tabulated include several, if not many, of the same birds recorded in previous or successive years, although freezing to death in winter appears not to be an uncommon fate of these birds. An intensive banding program would provide information on actual dispersal patterns from winter to spring and the turnover in the population. An owl photographed at a hole in an elm in Vermillion Park in Dauphin on 20 April 1973 was one of two birds that were possibly a mated nesting pair that occurred there that year (Figure 2).

Being neither highly vocal as in the spring or attracted to farmyards as in winter, screech-owls are much less frequently encountered in summer and fall. All three summer (June- August) records involved birds identified in June that had been located in spring (May) including a breeding pair discussed later in this paper.

In fall (September-November) an Eastern Screech-Owl arrived at a farmyard in aspen-willow habitat near a dry creek bed in early September 1986. A screech-owl was seen in the same area 5 November after a snowstorm $(\mathrm{H}$. Henderson, pers. comm.). A small owl with feather tufts perched on the gable of the log home of Tom and Laurie Zaporzan in Bur Oak woods for a day in the fall of 1992. A gray phase owl collided with the vehicle of Jim Bertwhistle and Patty Best when it flew from a spruce shelter belt just southwest of Dauphin on 28 December 1983. The injured owl was recovered, rehabilitated and released by the Bests.

The records presented document the owl in this region of Manitoba north of the Riding Mountains. This 


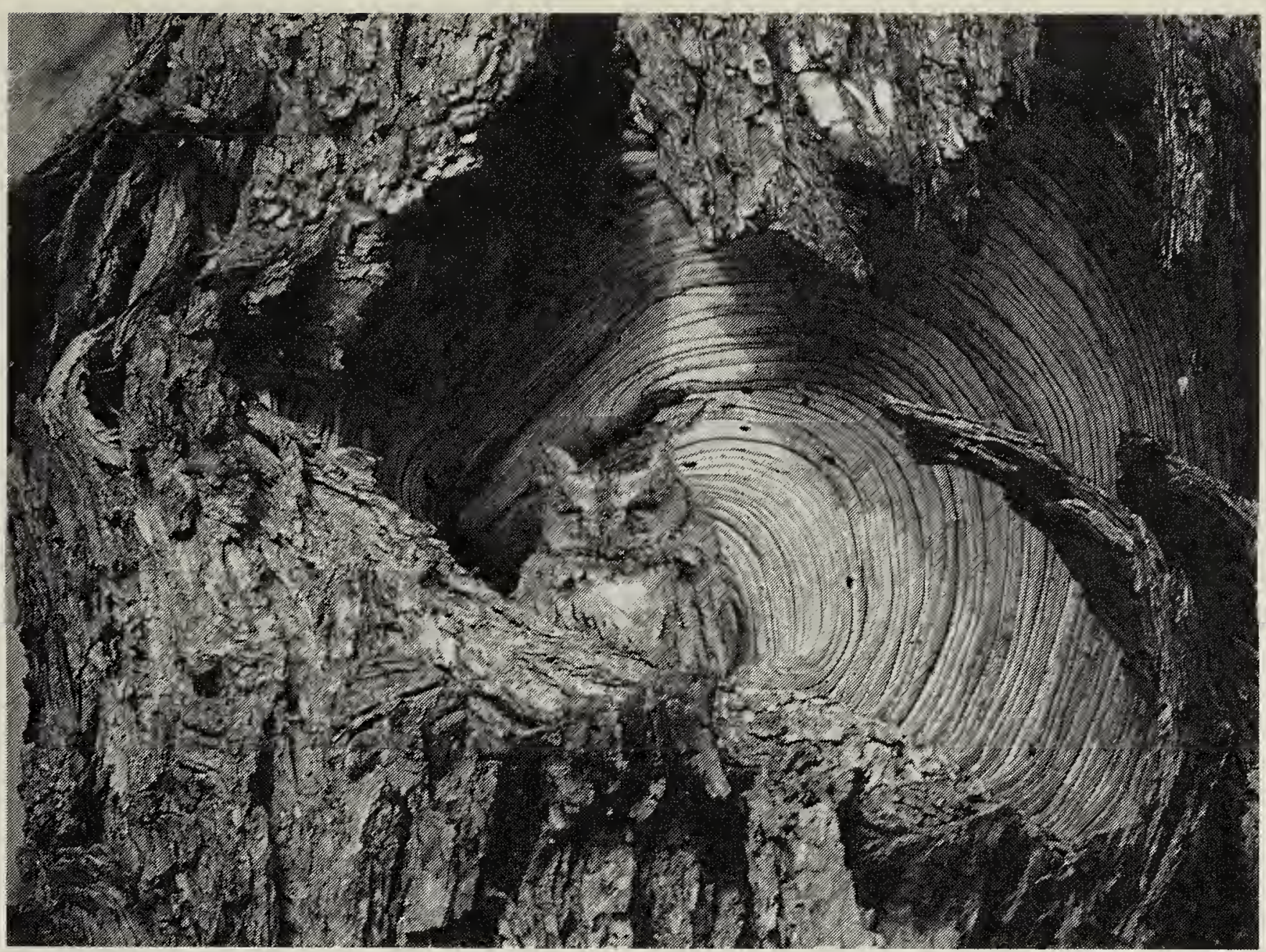

Figure 3. Male Eastern Screech-Owl (gray phase) in Vermillion Park.

report extends the breeding range of the Eastern Screech-Owl some 70 $\mathrm{km}$ north in Manitoba - the northernmost in the geographical range of the species. Prior to this study, the northernmost breeding record was the south boundary of RMNP at Wasagaming $\left(50^{\circ} 40^{\prime} \mathrm{N} ; 100^{\circ} 00^{\prime} \mathrm{W}\right)$ as observed by Richard Sutton in 1941 and reported by J. Dewey Soper. ${ }^{1,15}$

Breeding in Dauphin Located in Dauphin, Vermillion Park is situated between the Vermillion River and a meandering oxbow. Numerous stately old American Elms, Bur Oaks, Manitoba Maples and Green Ash trees grow throughout the park but primarily along the water courses. Dense subcanopy shrubs provide cover for wildlife in the northern natural sector of the five hectare park. A walking-jogging-skiing trail follows the perimeter of the park.
An Eastern Screech-Owl was located in the park on 25 April 1993 by Jim Wynes. Late that day we found the owl tranquilly sunning at the entrance to a cavity $8 \mathrm{~m}$ up on the south side of a mature elm (Figure 3). The tree was positioned less than $4 \mathrm{~m}$ from the west bank of the oxbow. Subsequent visits proved that the gray phase bird was a male and that the site was its main daytime roost.

Observations of the owl in the evening of 25 April had begun just prior to 8:10 p.m. when two Blue Jays arrived to taunt the raptor from a branch 3-4 m distant. Aroused, the owl opened its eyes wide and threatened its agitators with a gaping bill. Shortly, the jays flew eastward from whence they had come and the owl went back to dozing. At twilight (9:05 p.m.) the owl, with striking suddeness, opened its eyes widely, crouched and stared straight ahead. 
With feathers erected, it shook itself vigorously and with head lowered glowered left, then straight forward, left again and then right. Suddenly it took flight eastward $25 \mathrm{~m}$ across the oxbow where it perched and took up surveillance from a small stand of Manitoba Maples overlooking a 0.2 hectare area of dry Brome Grass (Bromus inermis) - a likely home for small rodents. The nightly flight across the oxbow to the maples later proved to be typical, although it sometimes flew westward. The owl was clocked at $39 \mathrm{~km} / \mathrm{hr}$ as it flew from the roost 18 May.

After dark on 12 May the male, carrying a Giant Water Bug (probably Lethocerus) ${ }^{11}$ in its bill, flew into a large Bur Oak on the west bank of the oxbow $30 \mathrm{~m}$ south of the roost tree. Viewed with a flashlight and binoculars, the prey-carrying owl faced northwest at its perch. After several minutes a soft whine was heard from that direction and soon the owl launched from the oak toward it. Lost from sight temporarily in the darkness, the male - without the bug - reappeared a few seconds later in a nearby tree. The prey had been delivered to an $11 \mathrm{~cm}$ diameter hole $3.8 \mathrm{~m}$ from the ground in the more southerly of two mediumsized maples which faced the oxbow $13 \mathrm{~m}$ to the east. This nesting tree was $15.3 \mathrm{~m}$ south of the male's main daytime roosting tree. Subsequent to the arrival of the male with food, the rusty-brown female flushed from the nest cavity and flew across the oxbow.

Periodic observations at the nest were made primarily before 12:00 p.m. In daylight, the female often roosted just inside the cavity entrance and remained there despite human activity on the hiking trail 10 $\mathrm{m}$ away or us some $25 \mathrm{~m}$ distant.
However, if looked at from close range, she quickly withdrew out of sight into the nest. Eventually she allowed us to photograph her from a ladder less than $2 \mathrm{~m}$ away. Was it by selection or by chance that the gray phase male had chosen a roost amid exposed gray wood and bark in and around the cavity entrance in the elm (Figure 3) while the rufous-brown female blended almost imperceptibly with the bark pattern and colouration around the cavity entrance to the nest (front cover). One hypothesis states that natural selection has produced cryptic colouration in owls according to prevailing local colour of bark, twigs and leaves. ${ }^{6,10}$ Our observations of roosting owls support this.

Owlet hissing and rasping was heard 14 May but the young could not be viewed, even with a flashlight and mirror, because of the angles of the tunnel from the entrance to the nest. Two owlets appeared at the cavity entrance on 1 June and three were seen there two days later. By 5 June four young were out of the nest and perched in nearby well-foliaged trees as observed by Larry Livingston. Three of these were as large as the adults, one of which, the female, roosted in the cavity entrance as noted by Livingston. A tiny fifth owlet peered from the entrance 6 June and this, or another small owlet, rasped for food at the cavity entrance 8 June while a larger youngster rasped from a tree on the east side of the oxbow. No others were heard or seen that evening even with an intensive search out to $100 \mathrm{~m}$ from the nest tree. A tiny owlet was still at the cavity entrance 9 June but was not seen there the following day. Two owlets rasped in trees $40 \mathrm{~m} \mathrm{NW}$ of the nest tree on 10 June, their cries for food carried well over $100 \mathrm{~m}$. 


\begin{tabular}{|c|c|c|}
\hline Species & $\begin{array}{c}\text { Delivered to Nest } \\
\text { by Male }\end{array}$ & $\begin{array}{l}\text { Delivered to Nes } \\
\text { by Female }\end{array}$ \\
\hline \multicolumn{3}{|l|}{ Insects } \\
\hline Giant Water Bug & 1 & \\
\hline Water Beetle & 1 & 3 \\
\hline Caterpillar & & 4 \\
\hline Unknown & 1 & 12 \\
\hline Total & 3 & 19 \\
\hline \multicolumn{3}{|l|}{ Mammals } \\
\hline Northern Flying Squirrel & 1 & \\
\hline Vole spp. & 1 & \\
\hline Total $^{4}$ & 2 & 0 \\
\hline \multicolumn{3}{|l|}{ Birds } \\
\hline Tennessee Warbler & 1 & \\
\hline Yellow-rumped Warbler & 3 & \\
\hline Wilson's Warbler & 1 & \\
\hline Empidonax Flycatcher & 1 & \\
\hline Chipping Sparrow & 4 & \\
\hline Clay-coloured Sparrow & 1 & \\
\hline Sparrow spp. & 1 & \\
\hline Total $^{4}$ & 12 & 0 \\
\hline \multicolumn{3}{|l|}{ Amphibians } \\
\hline Wood Frog & 1 & \\
\hline Frog spp. & 1 & 4 \\
\hline Total $^{4}$ & 2 & 4 \\
\hline \multicolumn{3}{|c|}{$\begin{array}{l}1 \text { all observations before } 12: 00 \text { p.m. } \\
2 \text { prey delivered directly to the nest cavity or transferred to female at rendezvous sites } \\
3 \text { no transfers from male to female observed }\end{array}$} \\
\hline
\end{tabular}

In the morning of 11 June, one owlet was located by William Moshenko about $90 \mathrm{~m}$ from the nest tree on the ground and was under impending attack from marauding Common Crows. The fate of this bird is not known and no owls were found that evening. If the owlet survived, it and the others faced other perils. By 2:20 a.m. on 12 June, $50 \mathrm{~mm}$ of rain soaked the area. That evening a large owlet was perched $6 \mathrm{~m}$ up in a Green Ash tree by the oxbow $70 \mathrm{~m}$ from the nest tree. Suddenly a violent thunderstorm struck with torrents of rain and winds so powerful that two giant trees nearby crashed to the ground and the upper brick wall on the south side of the Dauphin First United Church, about one block away, collapsed inward. When the storm ended, the young owl, who had good cover in the canopy, was seen to fly a short distance to another perch. Attempts to determine how wet its plumage was were unsuccessful because it was too far up. We believe five owlets were fledged from the nest. Some of the young are shown in Figure 5.

Prey The only three pellets found during the study were located at the base of the elm on 25 April. They all contained skulls and bones of small rodents. Identification of prey delivered was primarily made by Walley with a 20x spotting scope mounted on a tripod or with binoculars while the prey-bearing owl, often perched for several minutes at a rendezvous 


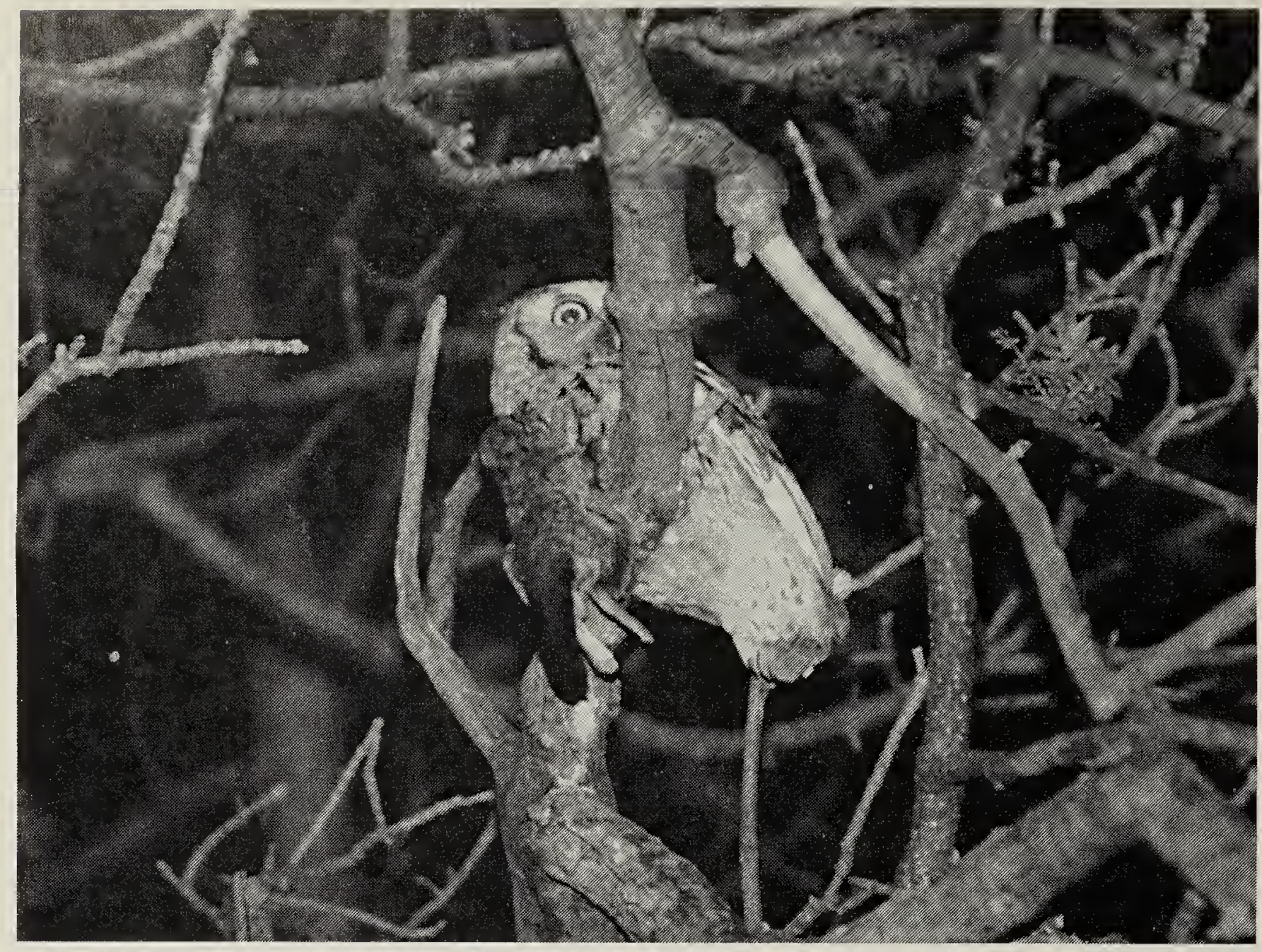

Figure 4. Female Eastern Screech-Owl (brown phase) with Northern Flying Squirrel.

site, was illuminated with a 6-volt battery-powered flashlight by Clyde. Because of the contrasting color differences, the respective sexes were usually identified, even in flight, with the light beam.

Eastern Screech-Owls are opportunistic predators taking whatever available prey they can subdue. In terms of items or biomass, many studies report a preponderance of small mammals, birds or insects in the diet of this raptor. $2,3,7,13$ In this study, prey delivered to the nest included invertebrates (all identified were insects) and vertebrates (Table 2). By item, songbirds made up $60 \%$ of the vertebrate diet compared to only $10 \%$ mammals. Two factors may help explain the low percentage of mammals taken. The clipped lawn of the park would not be expected to support many mice and the Brome Grass area east of the oxbow may have had its rodent population mark- edly reduced by the owls earlier. Identification of Tennessee, Yellowrumped and Wilson's Warblers (Table 2) as prey of the owls showed that, of songbirds, at least $41 \%$ were known transients in northern migration. We recognize that our observations do not necessarily represent the actual prey proportions of the owls. In one study, the earliest that feeding ceased was at 2:50 a.m., the latest was at 4:14 a.m., with up to 75 feedings in a given night. ${ }^{2}$ We rarely remained in the area past 11:50. A Northern Flying Squirrel was the largest prey delivered (Table 2 and Figure 4).

When the nest was first discovered on 12 May, two prey items were delivered to the cavity by the male. The female made all six trips to the nest on 15, 17, 20 and 21 May, where the sex of the adult was identified. Of these, three involved known transfers of prey to her by the male at ren- 


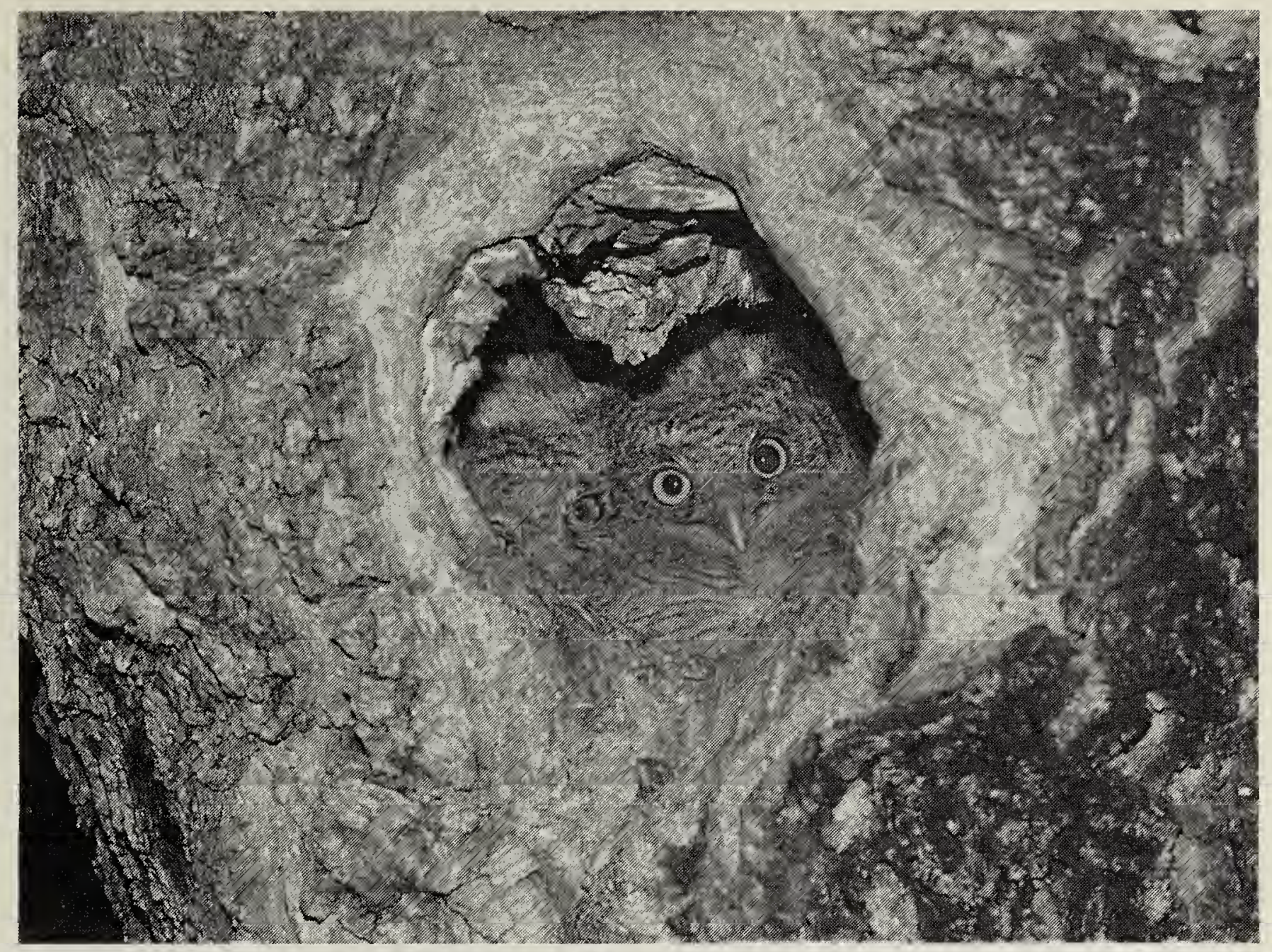

Figure 5. Eastern Screech-Owl nestlings.

dezvous sites located mainly on particular branches of three nearby trees within $30 \mathrm{~m}$ of the nest. These transfers were usually (we may have missed hearing some) preceded by the female's quavering whistle from close by. After 21 May only two of 35 trips to the nest involved known transfers of prey to the female, the respective sexes usually making deliveries directly to the cavity. Transfers may have occurred however, but often, as on 25 and 28 May, feeding was so rapid that one bird would be arriving as the other was leaving the nest. This suggested few or no transfers were being made. Also, on those dates it was impossible to identify all the prey as flights were directly to the cavity without the usual pauses before entering. The minute size of the prey indicated that insects or other invertebrates were being transported.

The female was never seen with avian or mammalian prey that had not been delivered to her by her mate. Of 14 birds and mammals captured on 10 discrete nights (Table 2) all were brought by the male to the female at the rendezvous site or to the nest cavity between 15 May and 3 June. Do these observations indicate that in this pair only the male captured birds and mammals?

One quiet evening at dusk, the male scanned the placid surface of the oxbow from its perch low in a maple near the east bank. Suddenly he flew out and seized a small unidentified animal in its talons from the water close to the west bank. Does the relatively calm surface of an oxbow, where movements of even a small insect are readily seen and/or heard by an owl, have advantages over locating such or similar prey on a rapidly flowing stream? At Vermillion Park, $44 \%$ of all known prey items were aquatic forms, the only 


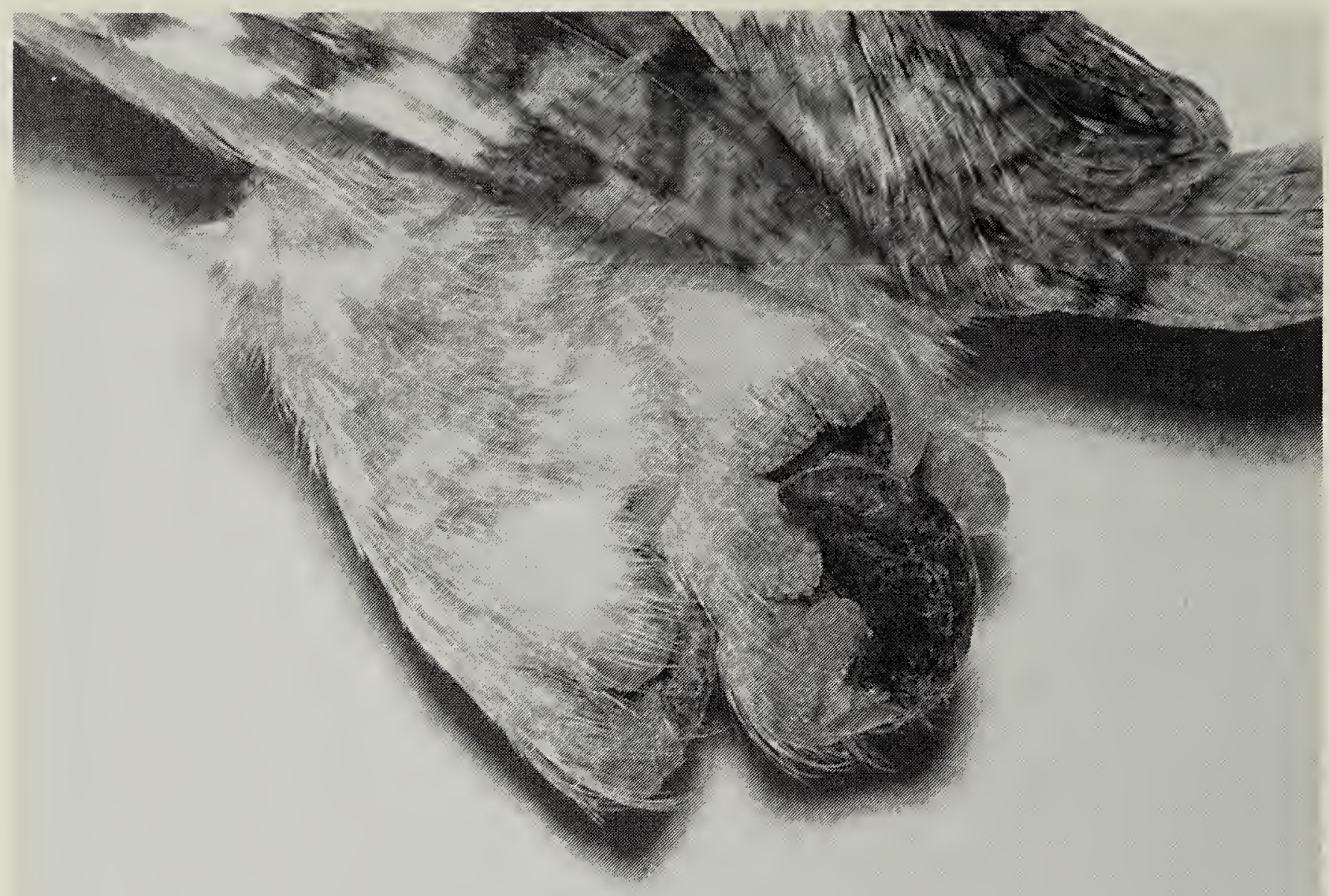

Figure 6. Tar-like material on talons of Eastern Screech-Owl.

possible sources of which were the still waters of the oxbow and the swift moving Vermillion River some $150 \mathrm{~m}$ west of the nest tree. All aquatic prey identified in the owls' bills were fauna typical of well vegetated stagnant pools, ponds or oxbows. ${ }^{11}$ These included frogs, Giant Water Bugs (Beisstomatidae) and Predaceous Diving Beetles (Dytiscidae), with an individual of the latter being identified from a transparency of the male with one in its bill. Perhaps running water contains too few available prey species or prey is too difficult to locate and/or catch. Robert Rockwell noted the importance of stagnant water to the Rocky Mountain Screech-Owl (Western Screech-OwI). ${ }^{2}$

\section{Colour Phases and Adaptation} Eastern Screech-Owls are polymorphic in plumage colour showing gray, brown or rusty-brown and red. 2,12, 14 Of 10 adult owls for which colour phase was positively known, seven were gray and three were brown. One of the brown owls was a frozen specimen found by Adrian Baker. Baker delivered another brown specimen to Walley. This road-killed bird picked up on 18 March 1976 had a peculiar tar-like material built up on the talons of the right foot (Figure 6). James Duncan suggested that it may have come in contact with this substance in a chimney. The third brown phase owl which was actually rusty-brown was the female of the mated pair in Vermillion Park in 1993.

Red phase screech owls are not well adapted to cold. The absence of this phase among the known colour phases in the region is consistent with observations made during a severe winter in northern Ohio where $44 \%$ more red phase screech-owls died than gray phase birds. There was no difference in mortality between the two phases in normal win- 
ters. ${ }^{8}$ Red phase screech-owls have significantly higher metabolic rates at temperatures below $-5^{\circ} \mathrm{C}$ and consume less energy above $5^{\circ} \mathrm{C}$ making them poorly adapted to cold. ${ }^{8}$ Natural selection in the northern part of its geographic range has been for gray and brown. Birds with these plumages have reduced metabolic energy costs in maintaining thermoregulation. ${ }^{8}$ The colour variations may be due to direct differences associated with heat conductance or radiation, or indirectly to physiological differences genetically linked to plumage colour. Nevertheless, in the winter of 1995, a red phase Eastern ScreechOwl was identified at Birtle, Manitoba $\left(50^{\circ} 25^{\prime} \mathrm{N} ; 101^{\circ} 10^{\prime} \mathrm{W}\right)$ some 130 $\mathrm{km}$ southwest of Dauphin. Naturalist Edgar Dandridge discovered the raptor feeding on a freshly killed Rock Dove in his shed in Trembling Aspen-Bur Oak habitat on the north crest of the Birdtail Valley.

Conclusion The tabulation of almost 50 records of the Eastern ScreechOwl in this agricultural region of Manitoba where none had previously been known to science, is striking. The dearth of previous records from this area of Manitoba might be explained by the fact that farmers and others did not know of anyone to report sightings to until the senior author arrived in Dauphin in 1970 and began publishing results of Christmas Bird Counts in the Dauphin Herald and general birding notes in the Winnipeg newspapers. In adjacent Saskatchewan, 20 records dating back to the early 1940 s are known for the Yorkton area. ${ }^{1}$

It is possible that the species was simply overlooked by avian scientists. National Museum of Canada ornithologists failed to identify the Eastern Screech-Owl in studies conducted in: 1920 (P.A. Taverner and H. Lloyd); 1937 (P.A. Taverner, A.H. Shortt and W. Watkins); 1938
(A.H.Shortt and R. Sutton); and 1951 (W.E. Godfrey and C.L. Thacker). ${ }^{4}$ As stated earlier in this study, the writers were unaware of any screech-owls in summer that had not been located in spring and even then only three instances were known the Vermillion Park breeding pair in 1993 and two others, both involving observations in early June only. All of the National Museum studies were conducted in summer when the owls are neither attracted to farmyards in quest of prey, as in winter, nor highly vocal as in spring, and therefore subject to being overlooked.

Acknowledgements Special thanks to Dr. James Duncan for constructive comments on the first manuscript, to Jim Wynes for reporting the male in Vermillion Park to us and to Adrian Baker for his many reports over the years on the owls at his farm. Thanks also to Dr. Robert Nero for providing pertinent reference material, to Dr. Hugh Hornbeck for the Kenville record, to Larry Livingston for his observations of the young leaving the nest cavity and to dozens of people who reported the owls to us over the years.

1. ADAM, C.I.G. 1989. Eastern ScreechOwl in Saskatchewan and adjacent areas. Blue Jay 47:164-188.

2. BENT, A.C. 1961. Life histories of North American birds of prey. Part II. Dover Publications, N.Y.

3. CRAIGHEAD, J.J. and F.C. CRAIGHEAD Jr. 1969. Hawks, owls and wildlife. Dover Publications, N.Y.

4. GODFREY, W.E. 1953. Notes on birds of the area of intergradation between eastern prairie and forest in Canada. National Museum of Canada Bulletin 128:189-240.

5. GODFREY, W.E. 1986. The birds of Canada. National Museum of Canada, Ottawa. 595 pp.

6. MARSHALL, J.T. Jr. 1967. Parallel variation in north and middle Ameri- 
can screech owls. Monographs of the Western Foundation of Vertebrate Zoology, No 1.

7. MAZUR, K.M. 1992. Fall food of the Eastern Screech Owl in Manitoba. Blue Jay 50:33-35.

8. MOSHER J.A. and C.J. HENNY. 1976. Thermal adaptiveness of plumage color in screech owls. Auk 93:614-619.

9. NATIONAL GEOGRAPHIC SOCIETY. A field guide to the birds of North America. National Geographic Society. 464 pp.

10. NORBERG, R.A. 1987. Evolution, structure and ecology of northern forest owls. Pages 9-43 in Biology and conservation of northern forest owls (NERO, R.W., R.J. CLARK, R.J. KNAPTON, and R.H. HAMRE, eds). Symposium proceedings Feb 3-7 1987, Winnipeg, Mb. USDA Forest Service, General Technical Report RM-142.
11. PENNAK, R.W. 1953. Fresh-water invertebrates of the United States. The Ronald Press, New York 769 pp.

12. PUGH, R.H. 1946. Audubon land bird guide. National Audubon Society, Doubleday \& Co., Garden City, New York. 312 pp.

13. RITCHISON, G. and P.M. CAVANGH. 1992. Prey use by Eastern Screech Owls: seasonal variation in central Kentucky and a review of previous studies. J. of Raptor Res. 26:66-73.

14. ROBBINS, C.S., B. BRUNN and H.S. ZIM. 1983. A guide to field identification. Birds of North America. Golden Press, New York.

15. SOPER, J.D. 1953. The birds of Riding Mountain National Park, Manitoba, Canada. Wildife Management Bull. Series 2 No. 6, Ottawa.

16. VOOUS, K.H. 1988. Owls of the northern hemisphere. Collins Ltd., London. $320 \mathrm{pp}$.

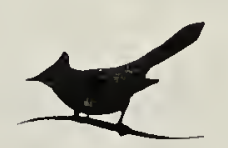

The raging monster upon the land is population growth. In its presence, sustainability is but a fragile theoretical construct. To say, as many do, that the difficulties of nations are not due to people but to poor ideology or land-use management is sophistic. If Bangladesh had 10 million inhabitants instead of 115 million, its impoverished people could live on prosperous farms away from the dangerous floodplains midst a natural and stable upland environment. It is also sophistic to point to the Netherlands and Japan, as many commentators incredibly still do, as models of densely populated but prosperous societies, Both are highly specialized industrial nations dependent on massive imports of natural resources from the rest of the world. If all the nations held the same number of people per square kilometer, they would converge in quality of life to Bangladesh rather than to the Netherlands and Japan, and their irreplaceable natural resources would soon join the seven wonders of the world as scattered vestiges of an ancient history. Wilson, E.O. 1992. The diversity of life. W.W. Norton and Company, New York. 424 pp. 